\title{
Quality of life of Elderly People with Hearing Impairment
}

Nahla Ashour Safaan ${ }^{1}$, Bahiga Galal Abd El-Aal ${ }^{2}$, Hala Abdel fatah Emam $^{3}$,Sabah E.

$$
\mathrm{Nady}^{4}
$$

${ }^{1}$ Professor of Family and Community Health Nursing, Faculty of Nursing - Menoufia University.

${ }^{2}$ Professor of Family and Community Health Nursing Faculty of Nursing - Menoufia University

${ }^{3}$ Nursing specialist at Ashmoun general hospital.

${ }^{4}$ Lecturer of Family and Community Health Nursing Faculty of Nursing - Menoufia University.

\section{Abstract:}

Background:Hearing impairment is the most common sensory deficit and a severe social and health problemthat can impair the exchange of information.It significantly impacts everyday life causing loneliness, isolation, and frustration, as well as communication disorders. So,it affects thequality of life.Aim:Determine the quality of life of elderly people with hearing impairment. Design:Descriptive Correlationaldesign.Subject:A purposive sample of 270 elderly people with hearing impairment attendedthe auditoryOutpatient clinics at AshmounGeneral Hospital affiliated toAshmoun district and ShebinElkom university Hospital at ShebinElkom district.Data CollectionInstruments:TwoInstrumentswere used to collect the data Instrument I:Structuredinterview that included two parts.Part1 concerned with socioeconomic demographic data, part2 included older people quality of life questionnaire with 35 items.Instrument II: Hearing handicap inventory for elderly screening version scale (HHIE-S). Results: The study revealed that $85.2 \%$ of elderly had significant hearing impairment based on (HHIE-S); and more than two thirds of them were suffering from severe to moderate hearing impairment and the least frequency was mild and profound according to their Audiometry; a negative correlation between HHIE-S and all quality of life domains and grand total quality of life score. More than half of elderlyperceived theirquality of life as poor. Conclusion:Every domain of quality of lifeas well as total quality of life affected negatively by severity of hearing impairment,indicating that quality of life gets poor with severity of hearing impairment. Recommendations:Early hearing screening withhigh quality screening protocols in the primary care setting and health education for elderly to increase awareness about periodic hearing examination.

Key words: Hearing impairment; Quality of life; Elderly. 


\section{Introduction:}

The ageing population is progressively and rapidly increased globally.Population aged 60 years or over numbered 962 million in 2017, more than twice as in the past and the number of older persons is expected to more thandouble in 2050, when it is projected to reach nearly 2.1 billion $^{(1)}$. According to World health organization elderly can be categorized elderly into three different groups: young old 60-74 year, old 75-84 year, and oldest old >85 years $^{(2)}$.

Elderly population has many medical problems. One of the top three chronic medical conditions is hearing impairment (HI) and it is considered the number one of communication disorder among older people. The expected increase in the Proportion of individuals aged at least 65 years worldwide is likely to be associated with an increasing the prevalence of $\mathrm{HI}$ among the elderly. $\mathrm{HI}$ is the most common sensory deficit in the elderly population andit is remains an invisible disability in elderly that is not obvious to others; therefore, it tends to be ignored, unlike other health problems. If HI left untreated, it will affect considerably not only on patients and caregivers, but the society as a whole ${ }^{(3-6)}$.
Hearing impairment is a known risk factor for functional decline, reduced social participation, withdrawal and accidents;so good functional hearing is critically important for elderly to be able to manage themselves and take care of their own $\operatorname{lives}^{(7,8)}$.

Hearing impairment have different causes, including advanced age,loud noise by longterm exposure to sounds that are either too loud or last too long resulting in permanent hearing impairment, earwax or fluid buildup can block sounds that are carried from the eardrum to the inner ear and health conditions in older people, as diabetes or high blood pressure .Hearing impairment can also result from taking certain medications as Ototoxic medications that can damage the inner ear (9-12)

Hearing impairment strongly associated with significant decrease in quality of life among older people. It is reported that elderly daily life affected by hearing impairment, since they have difficulties in exchanging information, in communicating with others, in make social relationships and engaging in public events and consequently reduce quality of life ${ }^{(13-17)}$. Hearing impairment could affect the individual's ability to communicate with 
others or limited communication because it impacts their everyday life, causing them to feel lonely, isolated and frustrated ${ }^{(12)}$.Hearing impairment also associated with depression, anxiety, frustration, social isolation, fatigue, interferes with understanding normal conversational speech and affects quality of life as a whole $^{(18,7,8)}$.

In communicatingwith hearing impaired patients nursesshouldconsider thesestrategies to receive the hearing impaired patient's attention before speaking, to make sure that elderly can be seen clearly, reduce unnecessary noise e.g. TV \& radio, face the light and patient at all times, do not hide your mouth when talking behind e.g. The hand or a paper, talk straight to the hearing impaired patient, do not have a conversation with other people on the same time, speak clearly and not too fast, and repeat or rephrase if necessary, all important facts should be written down and do never shout into someone's ear or hearing aid ${ }^{(19-22)}$.

The primary and main role of community health nurse with elderly people suffering from hearing impairment isearly detection ofHI by observing and assessing the level of hearing impairment by, asking question about changes in hearing, determine if symptoms occurred suddenly or gradually, decide if symptoms are unilateral or bilateral, inquire whether any prior treatment for hearing conditions, determine ifthe sensory effect of the condition onthe activity of daily living and then refer the elderly people for audiology investigation for diagnosis and treatment ${ }^{(23,24)}$.

\section{Significances of the study}

The World Health Organization expected that hearing impairment will become one of the top ten contributing factors to the burden of disease by $2030{ }^{\text {(25) }}$. This presents a growing problem because hearing impairment not only negatively affects the older adults' personal lives and the lives of their family members it increases the chance of becoming a potential burden to the society and the government ${ }^{(26)}$.

Globally, 360 million people (that constitute $5 \%$ of the world's population) live with disability due to hearing impairment; from those nearly 180 million people aged 65 years and older (that constitute $30 \%$ of the population in this period of age) have hearing impairment that interferes with understanding normal conversational speech. Despite highquality data available at national and local epidemiological on hearing loss, there is generally lacking awareness of the problem ${ }^{(2)}$.Approximately one in three 
people in the United States between the ages of 65 and 74 have hearing impairment, and nearly half of those older than 75 have difficulty hearing ${ }^{(27)}$.The prevalence of $\mathrm{HI}$ in the Egyptian elderly has been reported to be $44.3 \%{ }^{(28)}$.For this reason this study will be performed to determine the quality of life of elderly people with hearing impairment.

\section{Aim of the study:}

Determine the effect of hearing impairment on quality of life of elderly people.

\section{Research questions:}

What is the quality of life of elderly people with hearing impairment?

\section{Subjects and Method:}

\section{Studydesign:}

Descriptive Correlational design was used to fulfill the aim of the study and answering the research question.

\section{Setting:}

The study was conducted at Outpatient Audiology clinicsatAshmounGeneral Hospital affiliated toAshmoun district and ShebinElkom University Hospital at ShebinElkom district.

\section{Subjects:}

A purposive sample of 270 elderly people attended the previously mentioned settings for diagnosis and follow up who age 60 years or above, diagnosed with permanent hearing impairment, have no disabilities in other parts of the body or devastating conditions such as cancer and renal failure and didn't wear hearing aid.

\section{Sample size and power of the study:}

In order to calculate the required sample size to determine the quality of life of elderly people with hearing impairment, the Epi website was used to calculate sample size, the assumptions were the following:

- Population size (for finite population correction factor or $\mathrm{fpc})(\mathrm{N}): 1000$

- Hypothesized \% frequency of outcome factor in the population (p):44\%+/-5

- Confidence limits as \% of 100(absolute +/- \%)(d):5\%

- Design effect (for cluster surveysDEFF): 1

- Sample Size (n) for Various

Confidence Levels

\section{Equation:}

\section{Sample size}

$$
\begin{aligned}
& n=\left[\operatorname{DEFF}^{* N p}(1-\mathrm{p})\right] /[(\mathrm{d} 2 / \mathrm{Z} 21-\alpha / 2 *(\mathrm{~N}- \\
& \text { 1) }+\mathbf{p} *(1-\mathrm{p})]
\end{aligned}
$$

Used 95\% confidence intervals, with a sample size of 275. We approximate it into 270 elderly as the study sample ${ }^{(29)}$.

\section{Instruments of data collection:}

Twoinstruments used to collect the study data. 
Instrument I:Structured interviewing included two parts.

Part 1: Concerned with socioeconomic demographic data of the study subjects that developed by the researcher. Consisted of name, age, sex, address, education, with whom do you live, marital status, income, occupation, helping from others, type of helping and grades of hearing impairment which takenfrom audiometer.

Part 2: Included short form of older people quality of life questionnaire (OPQOL-with 35 items) that developed byBowling and Gabriel ${ }^{(30)}$;to assess quality of life of the elderly. Thisquestionnaire included eight domains of quality of life. These domains ( life over all, health, social relationship, independence, control over life and freedom, home and neighborhood, psychological and emotional well-being, financial circumstances and leisure activities). The OPQOL consisted of 35 statements, that required the participants to indicate to what the extent to which he/she agrees with each statement by selecting one of five possible options :strongly disagree, disagree, neither agree nor disagree, agree and strongly agree, each with a score of 1-5.

\section{Scoring system of OPQOL:}

The 35 statements of the full OPQOL questionnaire cover life overall,health, independence, control over life and freedom, home and neighborhood, psychological and emotional well-being, financial circumstances each of this domains included(4 items and scored 420).Social relationships (5 items andscored 5- 25), leisure and activities (6 items scored 6-30). The elderlybeing asked to indicate the extent to which he/she agrees with each statement by selecting one of five1 - 5 Likert scale (1=strongly disagree, $2=$ disagree, $3=$ neither agree nor disagree, $4=$ agree and $5=$ strongly agree, each with a score of 1-5). The total score ranges from 35 (worst possible QOL) to 175 (best possible QOL). The total score of each elderly was categorized into "poor QoL" when the elderly achieved $<110.99$ of the total score, and "good QoL" was considered when he/she achieved $\geq 110.99$ of the total score.

Instrument II:The Hearing Handicap Inventory for the Elderly Screening version (HHIE-S)scale developed by Ventryand Weinstein ${ }^{(31)}$.It was used to assess the degree of hearing impairment.

\section{Scoring system ofHHIE-S:}

The HHIE-S consist of 10 questions with (yes,no,or sometimes) the responses yes, 
scored 4score, sometimes scored 2 score and no, scored0score. After all questions have been answered the total score equal the sum of the scores assigned to each of the questions. The higher the HHIE-S score, the greater hearing impairment. The interpretation of score was the following: 0-8 indicated no hearing impairment, 1024 indicated mild to moderate hearing impairment and 26-40 indicated significant hearing impairment.

Validity and Reliability of the

\section{Instruments:}

\section{Instrument I:}

The (OPQOL-35) SF was previously validated on community-dwellingolder populations, and ethnically diverse population samples, in Britain ${ }^{(32)}$.The (OPQOL-35)SF was further tested among geriatric service out-patients in Milan, Italy, Cronbach's alpha coefficient for the Italian outpatient population enrolled in this study was found to be 0.78 , that indicated for internal consistencyand shown to have excellent applicability to cognitively normal older people ${ }^{(33)}$.

\section{Instrument II:}

The HHIE-S version was translated into Japanese and reported a high reliability (Cronbach's alpha coefficient of 0.92) and good validity (Pearson's correlation coefficient of 0.53) in Japanese outpatients ${ }^{(34)}$ The sensitivity and specificity of HHIE-S are approximately $75-80 \%$ for identifying hearing impairment of moderate or greater degree ${ }^{(35,36,31)}$.Internal consistency reliability (Cronbach's alpha) coefficients have been reported between 0.87- 0.91 in a sample of older adults with hearing problems ${ }^{(31,37,38)}$. Test-retest reliability was reported as 0.80 $0.85^{(39,40)}$.

Validation of the instruments was tested for its content validity and face validity by three experts in field of Family and Community Health Nursing and one expert in Geriatric nursing in Menoufia University who reviewed these instruments and recommended it for its consistency and adequacy.

\section{Pilot study:}

Pilot study was conducted on 27 elderly who represent $10 \%$ of the total sample with hearing impairment. The subjects of the pilot study were not included in the total sample of the research work. The Pilot study was carried out to test the applicability and clarity of the tools and detect any problems that might arise during the actual data collection. According to the results of the pilot study, the necessary and needed modifications and clarification were carried out, and then final form was finalized and used in data collection. 


\section{Administrative \&Ethical considerations:}

- Approval of ethical research committee was obtained at Faculty of Nursing Menoufia University.

- An official permission was obtained from the director of hospital to carry out this study, after submitting a letter from the dean of faculty of Nursing Menoufia University explaining the purpose of the study and method of data collection.

- Oral and written consent was obtained from the participants who were willing to participate in the study after explanation of study purpose.

- Subjects of the study were assured for confidentiality of the information and collected data used only for research.

\section{Data collection procedures:}

- This study was conducted in a period of 8 months starting from May to December 2019.

- After obtaining approval and the informed consent was taken from each participant to conduct the study, the researcher was introduced herself with brief explanation about the purpose of study to the subjects.

- An interviewwas conducted by researcher with each participant to explain the purpose of the study and its importance. The data collection procedures were done with the subjects who fulfill the criteria of selection of the present study.

- The researcher collected the required data every day per weak except Friday from 9A.M to12P.M from Outpatient audiology clinics at Ashmoun General Hospital affiliated to Ashmoun district and ShebinElkom University Hospital.at ShebinElkom district.

- Duration and time required for each interview were different from one participant to another depending on participant's readiness.

- The subjects who have sever or profound hearing impairment take much time for more clarification and the researcher asked the relatives for helping and researcher may write some words tohelp them in understanding.

- The researcher was present with each subject to the doctor to take the hearing impairment grades and ask the doctor about hearing measurement.

- The subjects were asked to fill the questionnaires and for subjects they can't write the researcher fill it.

- The interview for each subject took about 20-25 minutes to collect the required data.

- The obtained data was organized and secured for data analysis. 


\section{Statistical analysis:}

Data were collected, tabulated, entered and statistically analyzed by using SPSS (Statistical Package for Social Science) version 22. Graphics were done using Excel program.

1. Quantitative data were presented by mean $(\mathrm{X})$ and standard deviation (SD). It was analyzed using student t- test for comparison between two means, and ANOVA (F) test for comparison between more than two means.

2. Qualitative data were presented in the form of frequency distribution tables, number and percentage. It was analyzed by chi-square $(\chi 2)$ test. However, if an expected value of any cell in the table was less than 5, Fisher Exact test was used( if the table was 4 cells), or Likelihood Ratio (LR) test (if the table was more than 4 cells). Correlation coefficient ( $r$ ) was used to test the correlation between total score of HHIE-S with the grand total score of QoL as well as total score of each of its eight domains.Level of significance was set as $\mathrm{P}$ value $<0.05$ for all significant tests.

\section{Results:}

Table 1: Showed the distribution of elderly subjects according to their socio demographic characteristics. The findings in the table showed that approximately three quarters $(73.7 \%)$ of them were in age group 60 - 69 years, 58.1\%were widowed, and $50.7 \%$ were males. Near two thirds $(62.2 \%)$ of them were living with offspring, more than half $(52.6 \%)$ of them had not enough income, $47.8 \%$ of them not work, and $37 \%$ of them get help from others basically financial help. Table 2: Illustrated that the majority of elderly within the four grades of HI either mild, moderate, sever or profound, perceived that they had significant hearing impairment $(89.3 \%, 65.5 \%, 93.9 \%$, and $96.6 \%$ respectively). This result might indicate that once the elderly feel there is hearing impairment even if mild or moderate grades; his/her perception is that he/she has significant hearing impairment. There was a significant difference between elderly grades of audiometry hearing impairment and self-reported grades by HHIE-S.

Table 3:Showed negative correlation between HHIE-S total hearing impairment score and all quality of life domains $\mathrm{p}<$ 0.05 for all domains. Moreover there was negative correlation between HHIE-S total hearing impairment score and grand total quality of life score. This means that quality of life gets poor with increased hearing impairment and that develop 
support to the answer of the research question.

Table 4: Demonstrated the relationship between grand total Quality of life score of elderly and their hearing impairment grades. From the table, more than half $(53.7 \%)$ of subjects who were suffering from hearing impairment perceived poor total score of QoL; while $46.3 \%$ of elderly subjects xbg;pawl perceived good overall QoL this means that QOL affected with $\mathrm{HI}$ and reduced. So the research question has been answered.

Table 5 :Showed that there was no statistical significant differences between the elderly' socio-demographic characteristics and hearing impairment grades ( $>$ > 0.05) for each; except occupation. Elderly subjects who are in free work had higher percentage of significant hearing impairment than the other two groups not work $(82.9 \%)$ or retired $(82.3 \%)\}, P=0.03$.

Table 6: Revealed that, there were no statistical significant differences between socio-demographic characteristics of elderly subjects and their quality of life ,this mean that meaning of QOLis same for elderly regardless their socio-demographic characteristics with $\mathrm{P}>0.05$ for each.

Fig.1: Distribution of hearing impairment grades of studied elderly subjects according to their self- reported hearing impairment (HHIE-S).The figure revealed that the majority (85.2\%) of elderly had significant hearing impairment and the least of them had mild to moderate hearing impairment (14.8\%)

Fig.2: Illustrated that distribution of hearing impairment grades among studied elderly subjects according to their Audiometry (medical hearing measurement). From the figure, more than two thirds of studied elderly were suffering from severe to moderate hearing impairment $(36.7 \%$ and $31.1 \%)$ respectively and the least frequency was mild hearing impairment with $10.4 \%$, while $21.9 \%$ of them had profound hearing impairment 
Table1: Distribution of the studied elderly subjects according to their sociodemographic characteristics $(n=270)$

\begin{tabular}{|c|c|c|}
\hline Socio demographic characteristics & No. & $\%$ \\
\hline $\begin{array}{l}\text { Age groups } \\
60-69 \text { years } \\
70 \text { years or more }\end{array}$ & $\begin{array}{c}199 \\
71\end{array}$ & $\begin{array}{l}73.7 \\
26.3 \\
\end{array}$ \\
\hline $\begin{array}{l}\text { Residence } \\
\text { Urban } \\
\text { Rural } \\
\end{array}$ & $\begin{array}{l}143 \\
127\end{array}$ & $\begin{array}{l}53.0 \\
47.0\end{array}$ \\
\hline $\begin{array}{l}\text { Gender } \\
\text { Male } \\
\text { Female }\end{array}$ & $\begin{array}{l}137 \\
133\end{array}$ & $\begin{array}{l}50.7 \\
49.3\end{array}$ \\
\hline $\begin{array}{l}\text { Marital status } \\
\text { Single } \\
\text { Married } \\
\text { Divorced } \\
\text { Widowed } \\
\end{array}$ & $\begin{array}{c}0 \\
103 \\
10 \\
157 \\
\end{array}$ & $\begin{array}{c}0 \\
38.2 \\
3.7 \\
58.1 \\
\end{array}$ \\
\hline $\begin{array}{l}\text { Educational Level } \\
\text { Illiterate } \\
\text { Primary } \\
\text { Secondary } \\
\text { University degree } \\
\end{array}$ & $\begin{array}{l}165 \\
77 \\
16 \\
12 \\
\end{array}$ & $\begin{array}{c}61.1 \\
28.5 \\
5.9 \\
4.5 \\
\end{array}$ \\
\hline $\begin{array}{l}\text { Occupation: } \\
\text { Not working } \\
\text { Free work } \\
\text { Retired }\end{array}$ & $\begin{array}{l}129 \\
45 \\
96 \\
\end{array}$ & $\begin{array}{l}47.8 \\
19.7 \\
35.5 \\
\end{array}$ \\
\hline $\begin{array}{l}\text { Income: } \\
\text { Enough } \\
\text { Not enough } \\
\text { Enough and save }\end{array}$ & $\begin{array}{c}124 \\
142 \\
4 \\
\end{array}$ & $\begin{array}{c}45.9 \\
52.6 \\
1.5 \\
\end{array}$ \\
\hline $\begin{array}{l}\text { Living with: } \\
\text { Alone } \\
\text { Spouse } \\
\text { With offspring }\end{array}$ & $\begin{array}{c}30 \\
72 \\
168\end{array}$ & $\begin{array}{l}11.1 \\
26.7 \\
62.2\end{array}$ \\
\hline $\begin{array}{l}\text { Have help from others? } \\
\text { Yes } \\
\text { No } \\
\text { If yes, types of help }(\mathbf{N}=\mathbf{1 0 0}) \\
\text { Financial help } \\
\text { Physical help } \\
\text { Other help for life }\end{array}$ & $\begin{array}{c}100 \\
170 \\
90 \\
3 \\
7\end{array}$ & $\begin{array}{c}37.0 \\
63.0 \\
90.0 \\
3.0 \\
7.0 \\
\end{array}$ \\
\hline Total & 270 & 100 \\
\hline
\end{tabular}


Table 2: Relation between Audiometry hearing impairment grades and self-reported hearing impairment gradesof the study subjects $(n=270)$

\begin{tabular}{|c|c|c|c|c|}
\hline \multirow{2}{*}{$\begin{array}{l}\text { Audiometry } \\
\text { hearing } \\
\text { impairmentgrades }\end{array}$} & \multicolumn{2}{|c|}{ Self-reported hearing impairment grades } & \multirow[b]{2}{*}{$\begin{array}{l}\text { Total } \\
\text { N0.\% }\end{array}$} & \multirow[t]{2}{*}{ P value } \\
\hline & 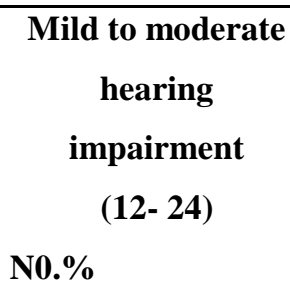 & $\begin{array}{l}\text { Significant hearing } \\
\text { impairment } \\
\qquad(26-40) \\
\text { No.\% }\end{array}$ & & \\
\hline Mild & 310.7 & 2589.3 & 28100 & \multirow{4}{*}{$\begin{array}{c}\mathrm{LR}=36.4, \\
\mathrm{P}=0.000 \\
\mathrm{HS}\end{array}$} \\
\hline Moderate & 2934.5 & 5565.5 & 84100 & \\
\hline Sever & 66.1 & 9393.9 & 99100 & \\
\hline Profound & 23.4 & 5796.6 & 59100 & \\
\hline Total & 4014.8 & 23085.2 & 270100 & \\
\hline
\end{tabular}

Table 3: Correlation between total hearing impairment score (HHIE-S) and total score of quality of life domainsof the study subjects $(n=270)$

\begin{tabular}{|c|c|c|c|c|c|c|c|c|c|}
\hline & $\begin{array}{c}\text { Grand total } \\
\text { QoL }\end{array}$ & $\begin{array}{c}\text { Life } \\
\text { overall }\end{array}$ & Health & $\begin{array}{c}\text { Social } \\
\text { Relation- } \\
\text { ship }\end{array}$ & $\begin{array}{c}\text { Indepen- } \\
\text { dence }\end{array}$ & $\begin{array}{c}\text { Home \& } \\
\text { Neighbor } \\
\text {-hood }\end{array}$ & $\begin{array}{c}\text { Psychologi } \\
\text {-cal } \\
\text { well-being }\end{array}$ & $\begin{array}{l}\text { Financial } \\
\text { Circumst- } \\
\text { ances }\end{array}$ & $\begin{array}{l}\text { Leisure, } \\
\text { religion }\end{array}$ \\
\hline Total HHIE-S & $r=-0.12$ & $r=-0.01$ & $r=-.05$ & $r=-.10$ & $r=-.02$ & $\mathrm{r}=-.21$ & $r=-.03$ & $r=-0.14$ & $r=-0.04$ \\
\hline hearing score & $P=0.04$ & $P=0.80$ & $P=0.37$ & $P=0.07$ & $P=0.70$ & $P=.000$ & $P=0.53$ & $P=0.02$ & $P=0.48$ \\
\hline
\end{tabular}

$\mathrm{r}=$ Correlation coefficient 
Table 4: Relationship between grand total quality of life score of elderly and their hearing impairment grades $(n=270)$

\begin{tabular}{|c|c|c|c|c|}
\hline \multirow[b]{2}{*}{$\begin{array}{l}\text { Groups of grand } \\
\text { total QoL score }\end{array}$} & \multicolumn{2}{|c|}{ Groups of total hearing score } & \multirow[b]{2}{*}{ Total } & \multirow[b]{2}{*}{$P$ value } \\
\hline & $\begin{array}{l}\text { Mild to moderate } \\
\text { Hearing } \\
\text { impairment } \\
(12-24)\end{array}$ & $\begin{array}{c}\text { Significant hearing } \\
\text { impairment } \\
(26-40) \\
\text { NO\% }\end{array}$ & & \\
\hline Poor QoL $(<110.99)$ & 2665 & 11951.7 & 14553.7 & \multirow{2}{*}{$\begin{array}{c}\mathrm{X}^{2}=2.4, \\
\mathrm{P}=0.12 \mathrm{NS}\end{array}$} \\
\hline Good QoL $(>=110.99)$ & 1435 & 11148.3 & 12546.3 & \\
\hline Total & 40100 & 230100 & 270100 & \\
\hline
\end{tabular}

Table 5: Relation between socio-demographic characteristics of studied elderly subjects and their hearing impairment grades $(n=270)$

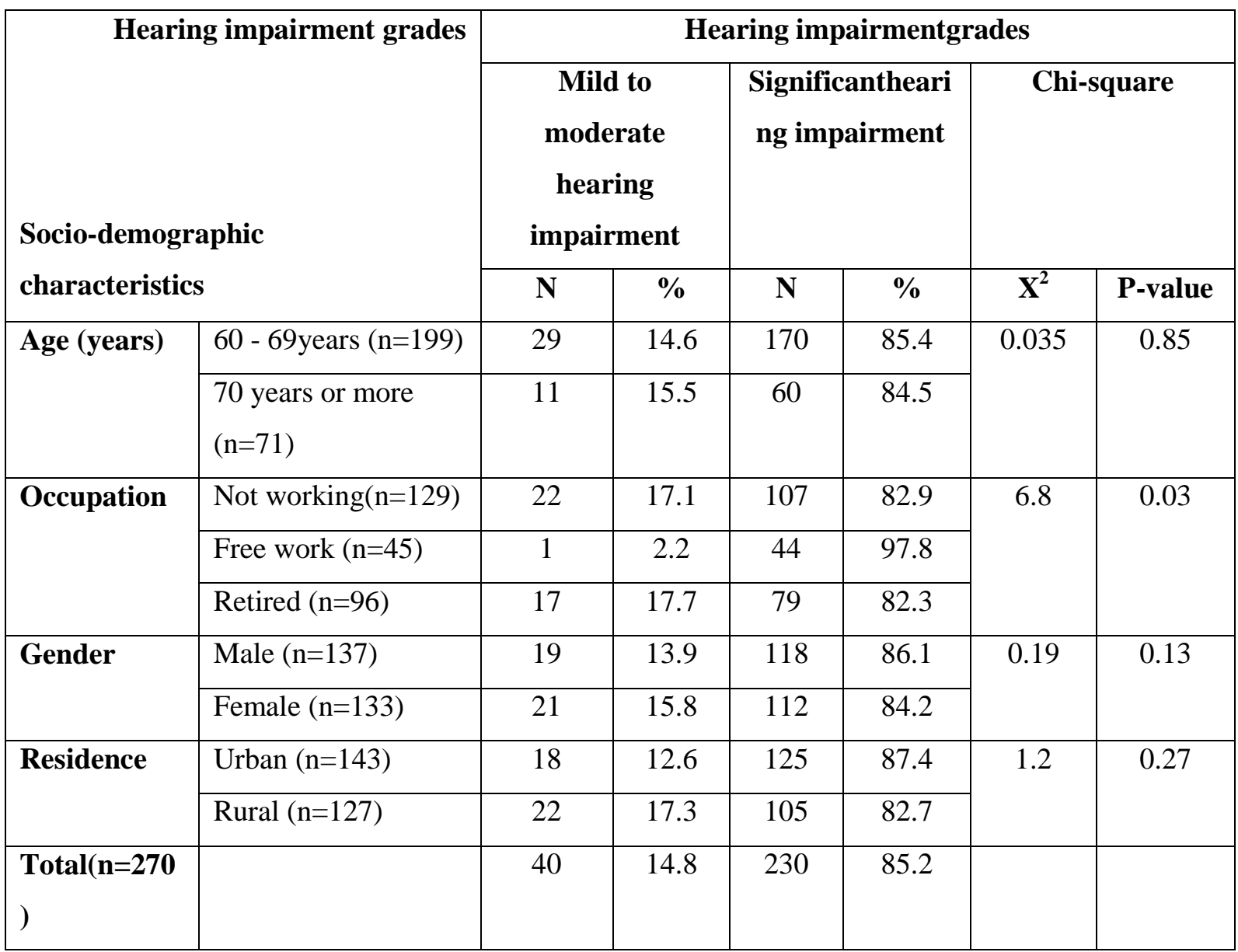


Table 6: Relation between socio-demographic characteristics of studied elderly subjects and their quality of life grades $(\mathrm{N}=270)$

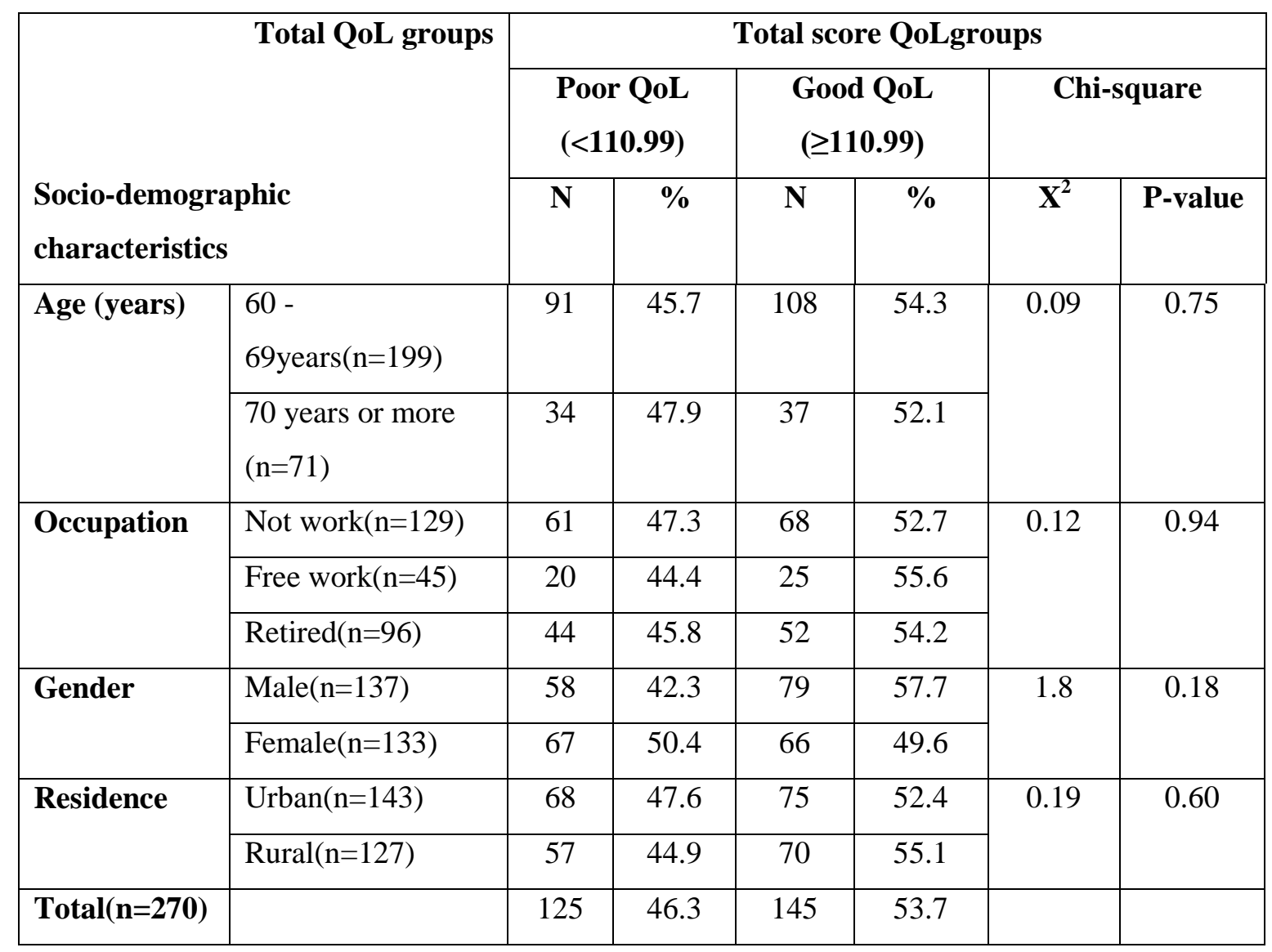

$\mathrm{NS}=$ No statistical significance $(\mathrm{P}>0.05)$ 


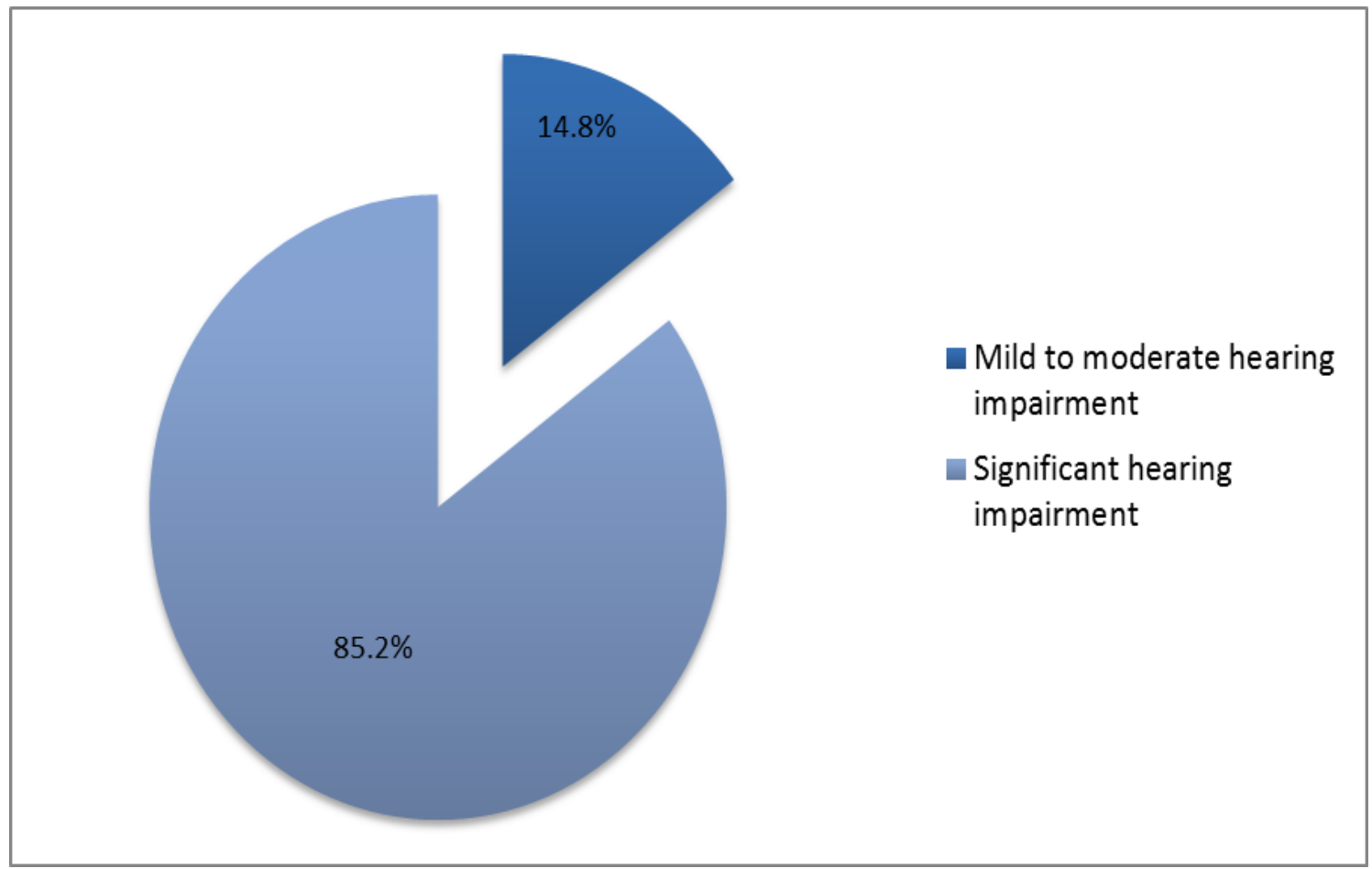

Fig.1:Distribution of the elderly subjects according to their self- reported hearing impairment based on(HHIE-S)scale ( $N=270)$

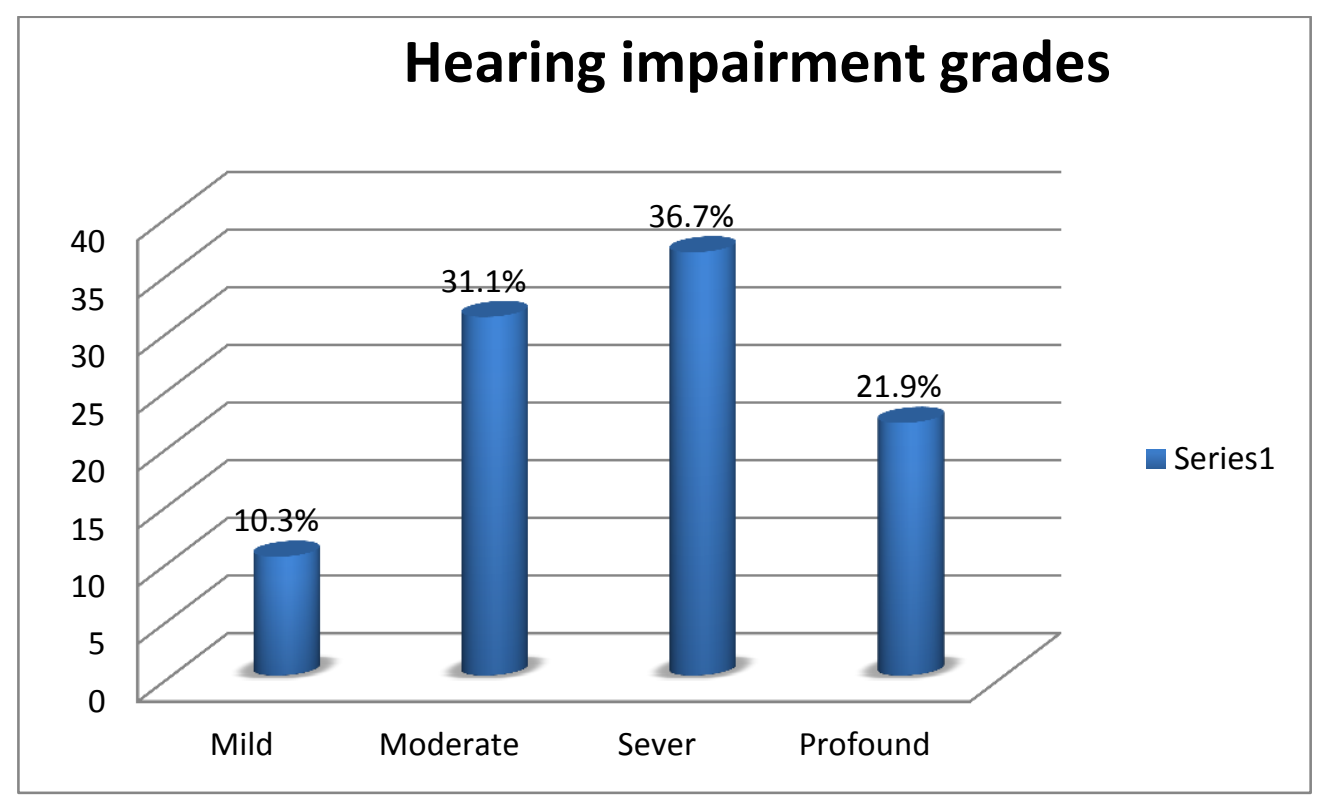

Fig.2:Distribution of the elderly subjects according to their hearing impairment grades based on audiometry $(\mathrm{N}=\mathbf{2 7 0})$ 


\section{Discussion:}

Hearing impairment (HI) is considered the third most prevalent chronic medical condition, and it is becoming a severe social and health problem. HI can impair the exchange of information, thus it significantly impacting everyday life, causing loneliness, isolation, dependence, and frustration, as well as communication disorders .So that, HI consequently reported to reduce quality of life (QoL). Hearing impairment considered the causative factor to the social isolation (6$8,41-43)$

Regardingsocio-demographic of studied elderly subjects the findings of current study illustrated that approximately three quarters of them were in age group 60-69 years, more than half of them were widowed, about two thirds were illiterates, more than half were living in urban area, and $50.7 \%$ were males. Near two thirds of them were living with their off spring's, more than half of them had not enough income, near half of them do not work, and more than one third of them get help from others basically financial help.

Regarding self-reported hearing impairment grades by HHIE-S, the present study indicated that the majority $(85.2 \%)$ of elderly had significant hearing impairment (severe and profound) this result supported by Mattosand Veras(2010) ${ }^{(44)}$ who carried out a study in Brazil and found that significant hearing loss was found in $82.4 \%$. Moreover in study conducted by Barriviera et al. (2013) $)^{(45)}$ in Northern Parana; their finding indicated that $91.56 \%$ of subjects had significant hearing loss. These slightly different findings may be due to the different criteria of each study sample and sample size. Regarding hearing impairment grades among studied elderly subjects according to their Audiometry the current results revealed that, more than two thirds of studied elderly were suffering from severe to moderate hearing impairment and least frequency of them were suffering from mild and profound hearing impairment. These results supported by El-Sayed (2016) ${ }^{(46)}$ who assess effect of hearing loss on quality of life among elderly in Zagazig City, Egypt, who reported that the most prevalent degree of hearing loss among the studied elderly was severe to moderate hearing loss. Moreover, a study conducted in Nigeria by Olaosunet al.(2013) ${ }^{(47)}$ they reported that the most prevalent degree of hearing loss was moderate to severe hearing loss.

Regarding relation between the grades of hearing impairment based on audiometry 
and self-reported hearing impairment, the result of the present study showed that there was a significant difference between the grades determined by audiometry and elderly self-reported hearing impairment as assessed by HHIE-S; this means the elderly perceived hearing impairment as a significant problem even if it is mild or moderate grades. This result supported by Polku etal. (2018) ${ }^{(17)}$ who study hearing impairment and quality of life among community-dwelling older adults in Finland, they found that perceived hearing difficulties(self-reported) in everyday life situations were more strongly associated with older adults' well-being than audiometrically assessed hearing impairment, as associations were observed with all the domains of QoL. Sothat it can be illustrated that perceived hearing difficulties had significant impact on daily life than measured by audiometry. So, along with audiometric measurements, health care practitioners should also take into account the effects that hearing problems on people's ability to manage in everyday life.

Regarding the total quality of life scores among the studied elderly subjects, the current study illustrated that more than half of studied elderly subjects perceived poor total quality of life based on their scores so research question has been answered, the current findings supported by El-Sayed (2016) ${ }^{(46)}$ who found that more than half of the studied elderly had low total quality of life score. Also Pelucchiet al. (2012) ${ }^{(48)}$ who study the impact of hearing loss on quality of life in older adult in Italy, they found that about two thirds of their studied subjects perceived poor total quality of life score.

In addition this result supported by Johnson et al.(2019) ${ }^{(49)}$ who carried out study about community based assessment of health-related quality of life in the elderly with hearing impairment in Bengaluru South in India they reported that about $51.75 \%$ of elderly with poor total quality of life score; Lasisi and Gureje (2014) ${ }^{(50)}$ who conducted study on disability and quality of life among elderly persons with self-reported hearing impairment from the Ibadan study of aging in Nigeria, they reported that there was a strong association between hearing impairmentand quality of life;QOL become poorer with HI. The result of thepresent study showed a negative correlation between total hearing impairment score and all quality of life domains (life over all, social relation, independence, home and neighborhood, psychological and emotional wellbeing, 
financial circumstances, leisure and activity). Moreover, also there was negative correlation between total hearing impairment score and grand total score of quality of life. This means that quality of life gets poor with increased hearing impairment; these results provide answer to the research question. These results came in the same line with those reported by Simpsonet al.(2016) ${ }^{(51)}$ who conducted a study in United States, health-related quality of life in older adults and hearing loss; they revealed that mild HL (hearing loss) appears to have a small effect on QoL and moderate/severe HL conferred a clear reduce of QoL;so it can be illustrated that, the severity of hearing impairment affected all quality of life domains and QOL decreased as a whole.

Concerning relation between sociodemographic characteristics(age, occupation, gender and residence)of studied elderly subjects and their hearing impairment grades the current study showed that no statistical significant differences between the elderly' sociodemographic characteristics and hearing impairment grades for each; except occupation. Elderly subjects who are in free work had higher percentage of significant hearing impairment than those who don't work or retired. These results supported byBraz et al.(2010) ${ }^{(52)}$ who found that no significant differences between hearing impairment and gender, age, residence andmarital status and also reported that worked elderly with hearing impairment more than retired. Moreover,Awadet al.(2016) ${ }^{(53)}$ they showed that there was no statistical significant difference between $\mathrm{HI}$ and socio-demographic data. That may be due to worked elderly more exposed to noise in work than retired and not working.

Concerning relation between $\mathrm{HI}$ and agethe current study showed there no statistical significant differences between $\mathrm{HI}$ and age, in spiteof therewere no statistical significant differences therewere slightly less three quarters of elderly subjectswere in age group $60-69$ years and this may be due early elderly seek medical health services than late elderly. This result was supported by Olaosunet al. (2013) ${ }^{(47)}$ who assessed effect of hearing loss on quality of life among older people in Nigeria and reported that more than two thirds of the studied subjects $(68 \%)$ were early elderly patients (aged $65-74$ years old). This may be due to the life expectancy in the African countries is low because of bad health care services. Also, Zhanget al.(2013) ${ }^{(54)}$ who study quality of life (QOL) and hearing impaired older 
Adults in Sanliurfa, Turkey;they found that about $72.9 \%$ of studied group in age group 59-69 that in the same line of the current results.

On the other hand this result is in disagreement with Mehmet et al. (2013) ${ }^{(55)}$ who study quality of life (QOL) and attitudes toward hearing impaired Older Adults in Sanliurfa, Turkey they reported that hearing impairment increased with age and studied sample had 75 years and over more than in early elderly. This difference may be due to most of sample participants in their study had age 75 years and over.

Concerning relation between sociodemographic characteristics of studied elderly subjects and their quality of life, the current results revealed no statistical significant differences between sociodemographic characteristics (age, occupation, gender and residence) of elderly subjects and their quality of life. These results supported by El $\operatorname{Kady}(\mathbf{2 0 1 2})^{(56)}$ who reported that no statistical significant differences were found between socio-demographic characteristics and QoL. This may due to that the quality of life should be the same meaning for every individual regardless of their socio-demographic characteristics.

\section{Conclusion:}

Based onthe findings of the current study, it can be concluded that hearing impairment significantly have negative effect on elderly's quality of life. The most affected domain of quality of life was life over all followed by social relation.

\section{Recommendations:}

- Early hearing screening with high quality screening protocols in the primary care setting is needed to determine people at risk of hearing impairment.

- Increasing elderly people awareness about the importance of regular hearing assessment for early detection and management.

- Health education for elderly to increase awareness about periodic hearing examination.

\section{References:}

1. Lee R, Zhou Y. Does fertility or mortality drive contemporary population aging? The revisionist view revisited. Population and Development Review. 2017; 1(1):285-301.

2. World Health Organization (WHO). Definition of an older or elderly person. World Health Organization. 2016. Available from: http://www.who. int/healthinfo/survey/ageingdefnolder/e n/. Accessed on 3 August 2017. 
3. Akeem L, Taiwo A, Oye G. The prevalence and correlates of selfreported Untreated Hearing Loss in adults. 2010; 27(1):827-48.

4. Vos T, Abajobir AA, Abate KH, Abbafati C, Abbas KM, Abd-Allah F, et al. Global, regional, and national incidence, prevalence, and years lived with disability for 328 diseases and injuries for 195 countries, 1990-2016: a systematic analysis for the Global Burden of Disease Study 2016. The Lancet. 2017; 390(10100):1211-59.

5. Wilson BS, Tucci DL, Merson MH, O'Donoghue GM. Global hearing health care: new findings and perspectives. The Lancet. 2017; 390(10111):2503-15.

6. Li-Korotky HS. Age-related hearing loss: Quality of care for quality of life. Gerontologist.2012;52(1):265-71. Available: https://www.ncbi.nlm.nih.g ov /pmc/articles/PMC4912548/

7. Haanes GG, Kirkevold M, Horgen G, Hofoss D, and Eilertsen G.: Sensory impairments in community health care: A descriptive study of hearing and vision among elderly Norwegians living at home. Journal of MultidisciplinaryHealthcare. 2014; 1(7): 217-225
8. Kvaal K, Halding AG, Kvigne $K$. Social provision and loneliness among older people suffering from chronic. A mixed-methods approach. Scandinavian Journal of Caring Sciences. 2014;28(1):104-111.

9. National Institute on Deafness and Other Communication Disorders (NIDCD).Age-Related Hearing Loss.Prospective effects of hearing status on loneliness and depression in older persons: Identification of subgroups. International Journal of Audiology.2017; $\quad$ 50(1): $\quad 887-896$ .Availablefrom: https://www.nidcd.nih. gov/health/age-related-hearing-loss

10. American Speech-Language-Hearing Association (ASHA). Untreated Hearing Loss in Adults-A Growing National Epidemic.2015.Available from:http://www.asha.org/Aud/Articles /Untreated-Hearing-Loss-in-Adult

11. Duthey B. Priority medicines for Europe and the world: A public health approach to innovation. WHO Background Paper. 2013;6 Available from: http://www.who.int/medicines/ areas/priority_medicines/BP6_21Heari ng.pdf. 
12. World Health Organization (WHO). Definition of an older or elderly person. World Health Organization. 2016. Available from: http://www.who.int/healthinfo/survey/a geingdefnolder/en/. Accessed on 3 August 2017.

13. Dawes P, CruickshanksK J, Fischer M E, Klein B E, KleinR, Nondahl D M. Hearing-aid use and long-term health outcomes: Hearing handicap, mental health, social engagement, cognitive function, physical health, and mortality. International Journal of Audiology.2015; $\quad$ 54(1): 838-844. doi:10.3109/ 14992027.2015.1059503.

14. Mick P, Parfyonov M, Wittich W, Phillips N, KathleenPichora-Fuller M. Associations between sensory loss and social networks, participation, support, and loneliness:Analysis of the Canadian Longitudinal study on aging. CanadianFamily Physician.2018; 64(1): 33-41.

15. Mick P, Kawachi I, Lin FR. The association betweenhearing loss and social isolation in older adults.Otolaryngology-Head and Neck Surgery.2014; 150(1): 378-384. doi:10.1177/0194599813518021

16. Sung YK, Betz J, Li L, Lin FR. Change in loneliness after intervention with cochlear implants or hearing aids. Laryngoscope.2017; 127(1): 18851889. doi:10.1002/lary.26424

17. Polku H, Mikkola TM, Rantakokko M, Portegijs E, Törmäkangas T, Rantanen T, Viljanen A. Hearing and quality of life among community-dwelling older adults. The Journals of Gerontology: Series B. 2018;73(3):543-52.

18. Costa TR,São Paulo SP: PontifíciaUniversidadeCatólica de São Paulo.Distúrbios de audição e a classificaçãointernacional de funcionalidade, incapacidade e saúde [tese]2013. 111.

19. Harkin H, Kelleher C. Caring for older adults with hearing loss: Identification of subgroups. International Journal of Audiology. 2011;50(1):887-96.

20. Larsby B, Hällgren M, Lyxell B, Arlinger S. Cognitive performance and perceived effort in speech processing tasks: Effects of different noise backgrounds in normal-hearing and hearing-impaired subjects. International Journal of Audiology. 2015; 44(3):131-43.

21. Dewane C. Hearing loss in older adults-Its effect on mental health. Social Work Today. 2010;10(4):18. Google Scholar. 
22. Lin FR, Metter EJ, O'Brien RJ, Resnick SM, Zonderman AB, Ferrucci $\mathrm{L}$, et al. Hearing loss and incident dementia. Ach Neurol. 2011;68(2): 214-220. Cross Ref Medline Google Scholar.

23. Cacchione ZP. Sensory changes. Hartford Journal of Geriatric Nursing.2012.Availablefrom:websiteht tp://consultgerirn.org/topics/sensory_c hanges/want_to_knowm

24. Wendling AL, Pimple C. Nursing management of hearing impairment in nursing facility residents. Journal of Gerontological Nursing. 2010; 34 (11): 917.

25. World Health Organization. Millions of people in the world have hearing loss that can be treated or prevented. 2013. Available from: http://www.who. int/pbd/deafness/news/Millionslivewith hearingloss.pdf. Accessed on 22-32015

26. Davis A, McMahon CM, PichoraFuller KM, Russ S, Lin F, Olusanya $\mathrm{BO}$, et al. Aging and hearing health: The life-course approach. The Gerontologist. 2016;56(2): 256-67.

27. National Institute on Deafness and other Communication Disorders. Center for hearing and communication statistics and facts about hearing
loss.2017.Availablefrom:http://chchear ing.org/facts-about-hearing-loss/.

Accessed on December 7,

28. Baran A, Muge F, Mehmet A, Hayriye K, Riza M. Effects of hearing aidsoncognitive functions and depressive signs in elderly people. Arch GerontolGeriatr. 2012; 25(1):114-120.

29. Epi website (Open Source Statistics for Public Health):2018. Available from:http://www.openepi.com/ SampleSize/ SSCohort. htm

30. Bowling A, Gabriel Z. Lay theories of quality of life in older age. Aging Soc. 2007;27(1):827-48.

31. Ventry IM, Weinstein BE. The hearing handicap inventory for the elderly: A new tool. Ear and Hearing. 1982;3(3):128-34.

32. Bowling A, Stenner P. Which measure of quality of life performs best in older age? A comparison of the OPQOL, CASP-19 and WHOQOL-OLD. Journal of Epidemiology \& Community Health. 2011;65(3):27380.

33. Bilotta $\mathrm{C}$, Bowling $\mathrm{A}$, Casè $\mathrm{A}$, Nicolini P, Mauri S, Castelli $M$, et al. Dimensions and correlates of quality of life according to frailty status: A cross- 
sectional study on community-dwelling older adults referred to an outpatient geriatric service in Italy. Health and Quality of Life Outcomes.2010;8(1):1-10.

34. Sano H, Hirayama H, Okamoto M, Setuyaku T, Suzuki K, Hara Y. A consideration of self-assessment for hearing handicap. Audiology Japan. 1994;37(1):395-6.

35. Deepthi R, Arvind K. Validation of the use of self-reported hearing loss and the hearing handicap inventory for elderly among rural Indian elderly population.2012. 22898672 DOI: 10.1016/j.archger.2012.07.006 .

36. Tomioka K, Okamoto N, Morikawa M, Kurumatani N.Self-reported hearing loss predicts 5-year decline in higherlevel functional capacity in highfunctioning elderly adults: The Fujiwara-Kyo Study. Journal of American Geriatrics Society. 2015;63(11): 2260-68. Available from:https://doi.org/10.1111/jgs.13780.

37. Yueh B, McDowell JA, Collins MP. Development and validation of theEffectiveness of Auditory Rehabilitation (EAR) scales. Arch OtolaryngolHeadNeck Surg. 2015; 131 (35):851-56.

38. Yueh B, Collins MP, Souza PE. Screening for auditory impairment- whichhearing assessment test [SAIWHAT]: RCT design and baseline characteristics.Contemporary Clinical Trials. 2012;28(32):303-315.

39. Milstein D, Weinstein BE. Hearing screening for older adults using hearing questionnaires. Clinical Geriatrics. 2007;15(5):21.

40. Pacala T, Bevan Yueh, Hearing deficits in the older patient: "I didn't notice anything"PMID..2012.305

41. Faller H, Schuler M, Richard M, Heckl U, Weis J, Küffner R. Effects of psycho-oncologic interventions on emotional distress and quality of life in adult patients with cancer: Systematic review and meta-analysis. Journal of Clinical Oncology. 2013, Feb;31(6):782-93.

42. Barile JP, Thompson WW, Zack MM, Krahn GL, Horner-Johnson W, Haffer SC. Activities of daily living, chronic medical conditions, and healthrelatedquality of life in older adults. J. Ambulatory Care Manag. 2012; 35 (4):293-304.

43. Carlsson P-I, Hjaldahl J, Magnuson A, Ternevall E, Edén M, Skagerstrand $\AA$ A,et al. Severe to profound hearing impairment: Quality of life, psychosocialconsequences and 
audiological rehabilitation.

Pharmacy Practice.

2019 ,

Disabil.Rehabil.2015;37(20):1849-56.

Jul;12(3):171.

44. Mattos CL, Veras PR. The prevalence of hearing loss in an elderly population in Rio De Janeiro: A cross-sectional study. Rev. Bras.Otorrinolaringol. 2010; 73(5):654-659.

45. Barriviera ML, Melo JJ, Marchiori ML. Hearing loss in the elderly: Historyof occupational noise exposure. Int. Arch. Otorhinolaryngol. 2013; 17 (2): 179-183.

46. Elsayed A. Effect of hearing loss on quality of life among elderly.Zagazig Nursing Journal. 2016; 12 (2147): 142149.

47. Olaosun OA, Ogundiran O, Tobin EJ. Hearing loss among elderly patients in an Ear Clinic in Nigeria. Advances in Life Science and Technology.2013; 14 (1): 81-86.

48. Pelucchi S, Ciorba A, Bianchini C, Pastore A. Clinical interventions in aging: The impact of hearing loss on the quality of life of elderly adults.Dove. Medical Press Ltd. 2012 ; 1(7):159-163.

49. Johnson P, Lavanya S, Abraham J, Kishore G. A community based assessment of health-related quality of life in the elderly population of Bengaluru South. Indian Journal of prevalence and correlates of selfreported hearing impairment in the Ibadan Study of ageing: Transactions of the Royal Society of Tropical Medicine and Hygiene. 2010, Aug;104(8):518-23.

51. Simpson AN, Simpson KN, Dubno JR. Health-related quality of life in older adults: Effects of hearing loss and common chronic conditions. Healthy Aging Research. 2015.

52. Braz J, Veras R., Mattos L. Audiology and aging: Literature review and present horizons. Otorhinolaryngol. 2010;73(1):122 -128.

53. Awad SA, Fahmy HD, El-Fatah A. Assessment of the quality of life among hearing impaired elderly patients' in Assiut University Hospital, Egypt. Assiut Scientific Nursing Journal. 2016; 4(8):1-0.

54. Zhang X,Mehmet T, Saaddine JB, Chou C-F. Quality of life (QOL) and attitudes toward hearing impaired older adults in Sanliurfa, Turkey. 2013; 47, 141-151.Available from: http://roa. sagepub.com/content/35/5/533 
55. Mehmet T, Zhang X, Saaddine JB, Chou C-F,Tobin EJ. Quality of life (QOL) and attitudes toward hearing impaired Older Adults in Sanliurfa, Turkey. 2013; 48, 139-151.Available from:http://roa.sagepub.com/content/35 $15 / 533$

56. El KadyH. Prevalence of hearing impairment and its correlates among elderly patients in Alexandria, Egypt. Egypt J. Otolaryngology.2012;27(1): $342-49$ 